Abstract

\title{
Composition Analysis and Anti-Cancer Properties of Two Endemic Phlomis Species (Phlomis cypria Post and Phlomis brevibracteata Turrill) from Cyprus ${ }^{\dagger}$
}

\author{
Imge Kunter * and Muberra Kosar \\ Faculty of Pharmacy, Eastern Mediterranean University, North Cyprus via Mersin 10, 99628 Famagusta, \\ Turkey; muberra.kosar@emu.edu.tr \\ * Correspondence: imge.kunter@emu.edu.tr; Tel.: +90-392-630-2868 \\ + Presented at the 3rd International conference on Natural Products for Cancer Prevention and Therapy, \\ Kayseri, Turkey, 18-20 December 2019.
}

Published: 26 December 2019

\begin{abstract}
Recently, different herbal compounds have been studied for their curative properties against Hepatocellular Carcinoma (HCC). There are over 100 Phlomis species native to the Mediterranean region, which have pharmacological activities against gastrointestinal system and liver diseases. Phlomis brevibracteata Turrill (PBT) and Phlomis cypria Post (PCP) are endemic plants of North-Cyprus belonging to the Lamiaceae family. In this study, chemical composition of the $70 \%$ methanol extracts of Phlomis species were analyzed by LC/MS/MS and antiradical activities were evaluated by DPPH ${ }^{\bullet}$ and $\mathrm{ABTS}^{+}$radical scavenging activity tests. Anti-carcinogenic activities on HCC cell lines were investigated using MTT and wound healing assays, intercellular ROS scavenging activities were tested by DCFH-DA assay. Forsytoside B and caffeoylquinic acids were found as the main phenolic compounds which are possibly responsible for antiradical activities of the plant extracts. Significant decrease in cell viability was noticed for both extracts at concentrations over $1000 \mu \mathrm{g} / \mathrm{mL}$. PBT treatment also resulted in cell motility inhibition. Additionally, both basal and induced oxidative states of all cell lines significantly were decreased by PBT. Since extracts showed cytotoxic, antioxidant and motility inhibitory activities, Phlomis species can be a good candidate for further studies with the goal of new anticancer chemotherapeutic discoveries.
\end{abstract}

Keywords: Phlomis; HCC; anti-carcinogenic activity

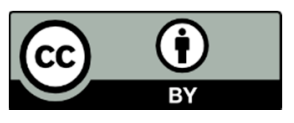

(C) 2019 by the authors. Licensee MDPI, Basel, Switzerland. This article is an open access article distributed under the terms and conditions of the Creative Commons Attribution (CC BY) license (http://creativecommons.org/licenses/by/4.0/). 